\title{
CORRESPONDENCE
}

\section{VENTILATED GLASS CONTACT LENSES}

\section{To the Editorial Committee of the British Journal of OpHTHALMOLOGY}

DeAR SIRS-I wonder if I may briefly comment on Mr. D. P. Choyce's paper on ventilated contact lenses (British Journal of Ophthalmology, 37, 100) in explanation of what might appear to be rather contradictory statements.

We read on p. 109 (8) that " discomfort does not appear to be any less in the ventilated lenses", and on p. 110 (9) that "veiling is almost as common with the ventilated type of lens "; yet statistical evidence shows that " an overwhelming majority of the patients who have worn both types prefer ventilated lenses" (p. $112(5))$.

When discussing discomfort, Choyce refers to its statistical incidence, not to its degree. The evidence that the permanent use of contact lenses, previously two in three, has improved to four in five since ventilation was introduced (Table VI, p. 107) is proof positive on this score. It might be of further help, perhaps, if I add that perforating anatomicallyfitted unventilated lenses, as was the starting stage in 1946, results in comparative discomfort in nearly all cases, and that it took some years before the requirements of functional haptics, as set out on p. 105, reached the present level. As all our clinical material, from the very first experimental cases, was pooled for the enquiry, it follows that discomfort in the early days must show in the final figures (Table XXI-XXII), however low the more recent rate of incidence. The author's statement about his own intolerance (p. 114) is not based on the type of contact lens upon which his survey is written.

Regarding veiling, Choyce rightly complains of the difficulty of using subjective reports for the statistical treatment of objective phenomena. However, Table XV offers excellent material for more exact analysis; Column 1 comprises cases of pre-corneal opacities (mostly froth, epithelial detritus, and mucous discharge), Columns 2 to 4, cases of epithelial oedema (Sattler's veil and peau d'orange veiling), Column 6 interstitial oedema and the " late" haloes (p. 105). Only Column 5 is doubtful, whereas Column 7 obviously refers to some pathetic reports of the near-blind who see as through a veil when without contact lenses. If Table XIV had been brought into correlation with Table XV, it would have shown that it is the late types of veiling (after 8 hours or more of continuous wear) that tend to persist the longest. Most pre-corneal opacities can be helped (e.g. froth by the use of castor oil, and mucous discharge by adequate treatment of its bacterial cause), and all early veiling can be prevented (see p. 105), and it is no great hardship to split up the day's wear into two separate periods of under 8 hours each, so it would appear that only an infinitesimal fraction of veiling exists for which no immediate remedy is available. This, I submit, is an important pointer towards the " entirely new ideas" the author postulates if further advances are to be made. If only it were common knowledge that it is wrong to leave contact lens wearers to their own resources, and common practice that all should call back at regular intervals for a routine check-up, the present rate and degree of success would be certain to rise materially.

May I finally point out some inaccuracies that affect me personally. Bier is stated as reporting on the effects of ventilation in 1943; this date is presumably quoted from his 
account of his Patent 592055, applied for in 1945 but not published before 1947, so that, far from any report, not even any technical publication on ventilated contact lenses was in existence before my clinical findings appeared in your Journal in 1946.

Also, the statement that I am responsible for training the fitters "working in other centres" should read " working in other centres under the same auspices".

\section{Contact Lens Centre, \\ 18 Cavendish SQuare, LONDON, W.1.}

$$
\text { I am, Sirs, }
$$

Yours obediently,

J. Dallos

February 20, 1954.

\section{BOOK REVIEW}

Virus Diseases in Man. (Viruserkrankungen des Menschen). By W. D. Germer. 1954. Pp. 190, 47 figs (including 8 col.). G. Thieme Verlag, Stuttgart (30 DM.; 52s. 6d.).

This book comprises a useful short summary of modern knowledge on virus diseases the more common of which are considered seriatim after a useful preliminary review of the techniques of investigating and cultivating these organisms. Of the general virus diseases many, such as those responsible for measles, smallpox, polioencephalitis, encephalitis, molluscum contagiosum, herpes simplex and zoster, and so on, have a considerable ophthalmological interest, sometimes incidental, sometimes very real; others, such as those responsible for trachoma, inclusion blennorrhoea, and epidemic keratoconjunctivitis, are peculiar to the province of this specialty. These are all briefly discussed with short bibliographies of the more important literature.

\section{BOOKS RECEIVED}

Biologie du cristallin (Report presented to the Société française.d'ophtalmologie).

By J. Nordmann. 1954. Pp. 730, 169 figs, 39 tables, bibl. Masson, Paris.

As an extensive review of this book will appear in Ophthalmic Literature, it is not proposed to make it the subject of a review in this Journal.

\section{NOTES}

The Illuminating Engineering Society has conferred Honorary Membership upon Sir John Herbert Parsons who is a past-president of the Society and was the first chairman of its Council. 